\title{
Photograph Locations
}

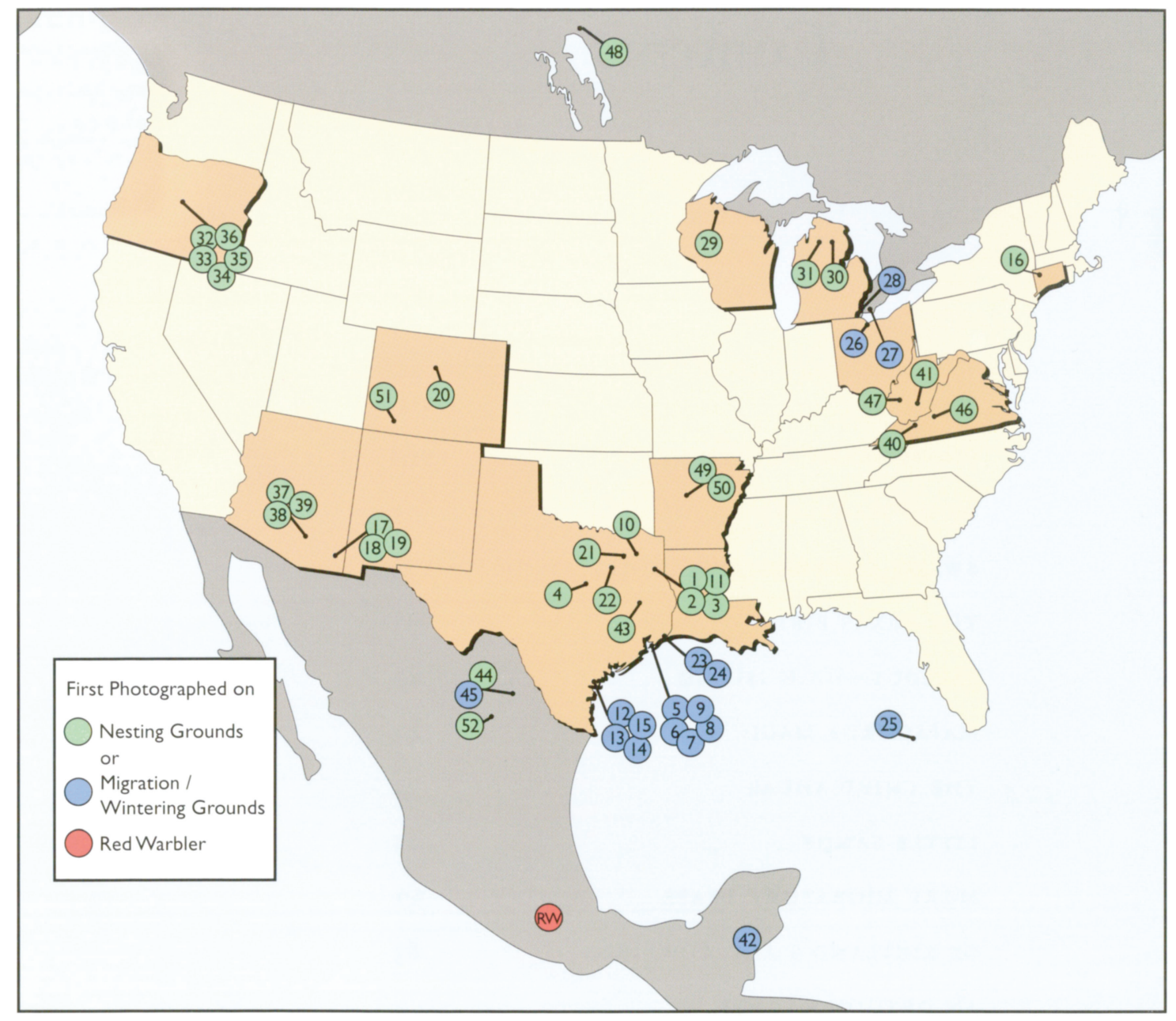

YEAR NO. NAME

LOCATION

PAGE

I987 I Prothonotary Warbler

Caddo Lake, Texas

12

19882 Yellow-throated Warbler

Caddo Lake, Texas

17

19883 Northern Parula

near Uncertain, Texas

I9

19894 Golden-cheeked Warbler

Meridian, Texas

22 